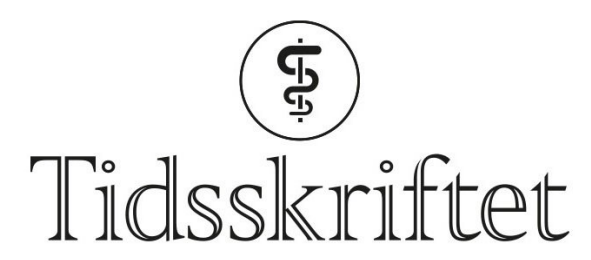

DEN NORSKE LEGEFORENING

\title{
Humane pancreasceller kan endres til insulinproduserende celler i mus
}

FRA ANDRE TIDSSKRIFTER

HAAKON B. BENESTAD

Universitetet i Oslo

I en ny studie ble humane $\alpha$ - og $\gamma$-celler fra pancreas reprogrammert til glukosesensitive, insulinproduserende celler i mus.

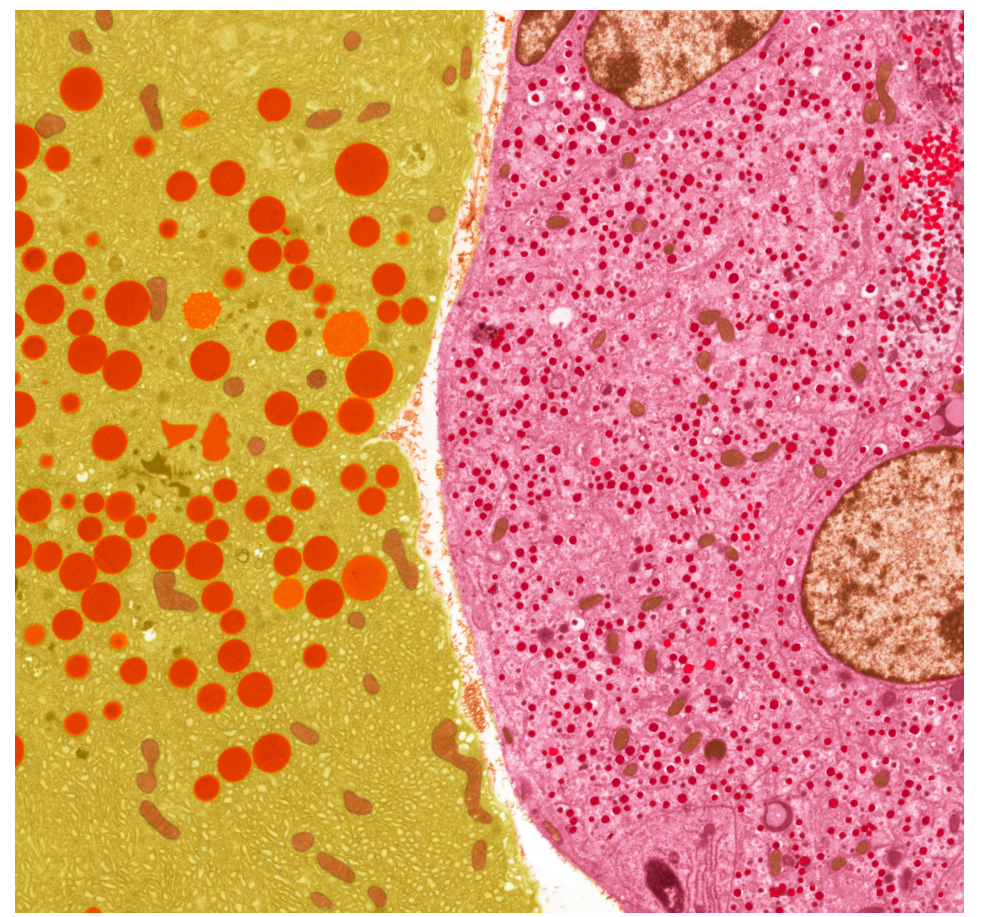

Pancreasceller sett gjennom transmisjonselektronmikroskop: eksokrin celle (gul) og endokrin øycelle (rosa). Illustrasjonsfoto: Science photo library / NTB scanpix

$\alpha$ - og $\gamma$-celler fra pancreas til avdøde donorer med eller uten type 2-diabetes ble i en ny studie omdannet in vitro til å bli insulinproduserende celler (1). Fra vevsbiter ble det laget enkeltcellesuspensjoner som med antistoffmerking og væskestrømscytometri ga suspensjoner med henholdsvis $\alpha$-, $\beta$ - og $\gamma$-celler. Ved hjelp av adenovirusvektorer ble cellene transdusert med fluoriserende protein (for å følge celledifferensieringen) og tre transkripsjonsfaktorer som kan være viktige for insulinsekresjon. Dissosierte $\beta$-celler som var reaggregert til pseudoøyer, utskilte insulin in vitro. Tilsetning av humane mesenkymale stamceller og endotelceller for å lage gunstige cellenisjer for øycellene økte 
insulinproduksjon. Aggregatene av øyceller skilte ut insulin etter glukosetilsetning in vitro og gjenopprettet normoglykemi hos immundefekte, diabetiske mus etter transplantasjon under nyrekapselen. Cellene var nedsatt immunogene overfor spesifikke T-lymfocytter fra pasienter med type 1-diabetes. Den høygradige transduksjonen ved to av transkripsjonsfaktorene økte ytterligere etter transplantasjon. Transplanterte celleøyer ble vaskularisert og innervert, og inneholdt et stort antall celler som var insulin-positive etter et halvår, som var den lengste observasjonsperioden.

- I tillegg til å gi ny kunnskap som kan være overførbar til andre typer celleterapi som nå forsøkes utviklet for type 1-diabetes, for eksempel stamcellebehandling, åpner disse funnene for nye og spennende behandlingsmuligheter, sier endokrinolog og professor Kåre I. Birkeland ved Avdeling for transplantasjonsmedisin ved Oslo universitetssykehus.

- Mest nærliggende er å tenke seg å bruke målrettede farmaka som kan transdifferensiere $\alpha$ celler til $\beta$-celler in vivo ved nyoppstått type 1-diabetes. En annen mulighet ville være å forbedre dagens øycelletransplantasjoner ved å øke innholdet i øyene av insulinproduserende celler. Omfanget og kvaliteten av dette arbeidet er imponerende, men det åpner jo ikke direkte for nye terapeutiske muligheter til pasienter, sier Birkeland.

\section{LITTERATUR:}

1. Furuyama K, Chera S, van Gurp L et al. Diabetes relief in mice by glucose-sensing insulin-secreting human $\alpha$-cells. Nature 2019; 567: 43-8. [PubMed][CrossRef]

Publisert: 6. mai 2019. Tidsskr Nor Legeforen. DOI: 10.4045/tidsskr.19.0236

(C) Tidsskrift for Den norske legeforening 2020. Lastet ned fra tidsskriftet.no 